University of Nebraska - Lincoln

DigitalCommons@University of Nebraska - Lincoln

\title{
Primed acclimation of cultivated peanut (Arachis hypogaea L.) through the use of deficit irrigation timed to crop developmental periods
}

\author{
Diane L. Rowland \\ USDA-ARS, dlrowland@ufl.edu \\ Wilson $\mathrm{H}$. Faircloth \\ USDA-ARS, Wilson.Faircloth@syngenta.com \\ Paxton Payton \\ USDA-ARS, paxton.payton@ars.usda.gov \\ David T. Tissue \\ University of Western Sydney, d.tissue@uws.edu.au \\ Jason A. Ferrell \\ University of Florida, jferrell@ufl.edu \\ See next page for additional authors
}

Follow this and additional works at: https://digitalcommons.unl.edu/usdaarsfacpub

Rowland, Diane L.; Faircloth, Wilson H.; Payton, Paxton; Tissue, David T.; Ferrell, Jason A.; Sorensen, Ronald B.; and Butts, Christopher L., "Primed acclimation of cultivated peanut (Arachis hypogaea L.) through the use of deficit irrigation timed to crop developmental periods" (2012). Publications from USDAARS / UNL Faculty. 1172.

https://digitalcommons.unl.edu/usdaarsfacpub/1172

This Article is brought to you for free and open access by the U.S. Department of Agriculture: Agricultural Research Service, Lincoln, Nebraska at DigitalCommons@University of Nebraska - Lincoln. It has been accepted for inclusion in Publications from USDA-ARS / UNL Faculty by an authorized administrator of DigitalCommons@University of Nebraska - Lincoln. 


\section{Authors}

Diane L. Rowland, Wilson H. Faircloth, Paxton Payton, David T. Tissue, Jason A. Ferrell, Ronald B.

Sorensen, and Christopher L. Butts 


\title{
Primed acclimation of cultivated peanut (Arachis hypogaea L.) through the use of deficit irrigation timed to crop developmental periods
}

\author{
Diane L. Rowland ${ }^{\mathrm{a}, *}$, Wilson H. Faircloth ${ }^{\mathrm{a}, 1}$, Paxton Payton ${ }^{\mathrm{b}}$, David T. Tissue ${ }^{\mathrm{c}}$, Jason A. Ferrell ${ }^{\mathrm{d}}$, \\ Ronald B. Sorensen ${ }^{a}$, Christopher L. Butts ${ }^{\mathrm{a}}$ \\ a USDA-ARS, National Peanut Research Laboratory, PO Box 509, 1011 Forrester Dr. SE, Dawson, GA 39842, United States \\ b USDA-ARS, Cropping System Research Lab, 3810 4th St., Lubbock, TX 79415, United States \\ c Plant Physiologist, University of Western Sydney, Hawkesbury Institute for the Environment, Richmond, NSW 2753, Australia \\ d Agronomy Department, University of Florida, 304 Newell Hall, Gainesville, FL 32611, United States
}

\section{A R T I C L E I N F O}

\section{Article history:}

Received 29 April 2012

Accepted 27 June 2012

Available online 19 July 2012

\section{Keywords:}

Water productivity

Irrigation scheduling

Root architecture

Drought stress

Water scarcity

\begin{abstract}
A B S T R A C T
Water-deficits and high temperatures are the predominant factors limiting peanut production across the U.S., either because of regional aridity or untimely rainfall events during crucial crop developmental periods. In the southern High Plains of west Texas and eastern New Mexico, low average annual rainfall $(450 \mathrm{~mm})$ and high evaporative demand necessitates the use of significant irrigation in production systems. In this west Texas study, the primary objective was to develop irrigation schemes that maximized peanut yield and grade while reducing overall water consumption. Therefore, a large-scale field experiment was established in 2005 and 2006 that utilized 15 treatment combinations of differing rates of irrigation (50, 75, and 100\% of grower applied irrigation) applied at different periods of peanut development (early, middle, and late season). Precipitation patterns and ambient temperatures showed greater stress levels in 2006 which likely reduced yields across all treatments in comparison to 2005. Yields were reduced 26 (2005) and 10\% (2006) in the lowest irrigation treatment (50\% full season) compared with full irrigation ( $100 \%$ full season); but early-season water deficit ( 50 and $75 \%$ in the first 45 days after planting) followed by $100 \%$ irrigation in the mid- and late-seasons were successful at sustaining yield and/or crop value. Root growth was significantly enhanced at 50\% irrigation compared with $100 \%$ irrigation, through greater root length, diameter, surface area, and depth, suggesting greater access to water during midand late-season periods. These results suggest that early to mid-season deficit irrigation has the potential to maintain peanut yield without altering quality, and to substantially reduce water use in this semi-arid environment.
\end{abstract}

(C) 2012 Elsevier B.V. All rights reserved.

\section{Introduction}

Achieving sustainability in global agriculture will ultimately depend on the water resources available to grow crops - whether through adequate and timely rainfall or through efficient irrigation application. Water scarcity and its escalating effects from climate change (IPCC, 2001) at present is the main environmental factor limiting crop production worldwide and is likely to remain

\footnotetext{
Mention of trade names or commercial products in this publication is solely for the purpose of providing specific information and does not imply recommendation or endorsement by the USDA.

* Corresponding author. Present address: Agronomy Department, University of Florida, 304 Newell Hall, Gainesville, FL 32611, United States. Tel.: +1 352273 3408; fax: +1352392 1840 .

E-mail addresses: dlrowland@ufl.edu (D.L. Rowland), Wilson.Faircloth@syngenta.com (W.H. Faircloth), paxton.payton@ars.usda.gov (P. Payton), d.tissue@uws.edu.au (D.T. Tissue), jferrell@ufl.edu (J.A. Ferrell).

1 Present address: 149 Fairethorne Drive, Leesburg, GA 31763, United States.
}

the most critical barrier to food production in the future (Chaves et al., 2003; Flexas et al., 2006). In U.S. agriculture, the issue is further complicated by competition for water resources between urban and agricultural users. To provide sustainable solutions, tools are needed to optimize water application in irrigated systems. Solutions provided to date rely primarily on deficit irrigation (DI) schemes which typically apply less irrigation throughout the season than is lost through evapotranspiration (Costa et al., 2007). The DI strategy deliberately allows the crop to sustain drought stress, thus often leading to partial loss of yield (Costa et al., 2007) which can be risky and economically unsuccessful for some crops (Fereres and Soriano, 2007; Geerts and Raes, 2009; Karam et al., 2011; Payero et al., 2006). DI at a single level over the entire growing season is increasingly a non-workable solution because, as climate conditions become more severe, crops cannot withstand lowered levels of irrigation applied during critical reproductive periods.

Several modified DI schemes have the potential to conserve water while maintaining yield and grade in peanut production including regulated deficit irrigation. Regulated Deficit Irrigation 
(RDI) was a term coined by Mitchell et al. (1984) and describes an irrigation management strategy utilizing deficit periods timed to certain crop developmental stages to control vegetative growth while maintaining yield (Girona et al., 1993). By timing reduced irrigation only during vegetative stages, this insures the crop does not experience drought stress during critical reproductive stages. One of the more promising RDI schemes reduces prereproductive water application in the early part of the crop season while maintaining full irrigation during the critical reproductive stages, and often through harvest. This technique has been shown in some cases to increase water productivity without a concomitant decrease in yield or quality (Chaves and Oliveira, 2004). This is particularly applicable in peanut since imposing water deficits during the early vegetative periods has been shown, in some cases, not to be detrimental to the crop and may have the potential to actually increase yield and dry matter production (Kheira, 2009; Ong, 1984; Rao et al., 1985). Additionally, exposure to drought stress during vegetative growth stages could serve to acclimate the crop to drought stress later in the season through changes in gene expression, modification to plant physiology and morphology, and eventual homeostatic compensation to the initial detrimental effects caused by the onset of stress (Flexas et al., 2006; Kottapalli et al., 2009). Acclimated plants often show improvement in their water relations and photosynthesis over non-acclimated plants under drought stress (Flexas et al., 2006) and can optimize their resource gain on a long term scale (Chaves et al., 2003). However, this RDI strategy has not been tested or shown to be successful in a typical commercial peanut production setting.

In early 2004, industry representatives and grower groups were calling for an evaluation of production strategies in peanut production for west Texas U.S., an area that was facing exhaustion of its aquifer resources. It is predicted that the primary water resource for agriculture in this region, the Ogallala aquifer, will be exhausted within 30-40 years (Opie, 2000; Perkins, 2002). Toward this end, a large-scale, on-farm research project was initiated investigating the effects of alternative deficit irrigation amounts timed to different developmental periods in peanut to enhance crop production under lowered irrigation application. It was hypothesized that early season deficits had the potential to acclimate the crop to later season drought conditions by priming both physiological and genetic responses. Therefore, the strategy of applying deficit amounts of water in the early season followed by full irrigation for the rest of the season was named primed acclimation (PA). There is a high probability that peanut will respond favorably to PA because it has high environmental plasticity (Awal and Ikeda, 2002) suggesting that it would be fairly tolerant to changes in irrigation application. Our specific objectives were: (1) to determine if reduced irrigation timed to particular developmental stages had the potential to improve crop performance as ultimately determined by yield and grade; and (2) to examine reproductive phenology, crop canopy responses, and root architecture in an effort to determine possible mechanisms that allow the crop to maintain production under reduced water application.

\section{Materials and methods}

\subsection{Field site and deficit irrigation treatments}

Field trials were conducted in 2005 and 2006 in Gaines County, Texas on a grower's peanut field under a quarter section pivot covering approximately 65 ha (Jimbo Grissom Farms). Fifteen irrigation schemes were tested using water application rates of 100 , 75 , and $50 \%$ of typical irrigation amounts for this region (in this case, typical rates were $25-37 \mathrm{~mm}$ per week, depending on the pumping capacity during the season, which resulted in $380-560 \mathrm{~mm}$
Table 1

Fifteen irrigation schemes for peanut tested in a grower's field in west Texas. Irrigation levels $(50,75$, and $100 \%$ of full irrigation) were applied during three peanut developmental stages (early =0-45 dap; $\mathrm{mid}=45-90$ dap, and late $=90$ dap - harvest). Irrigation and total water amounts (irrigation + rainfall) received during the growing season for 2005 and 2006 are given; total rainfall received during the growing season was $246 \mathrm{~mm}$ in both 2005 and 2006.

\begin{tabular}{rrrllll}
\hline \multirow{2}{*}{ Early } & Mid & Late & \multicolumn{2}{l}{ Irrigation $(\mathrm{mm})$} & \multicolumn{2}{l}{ Total $(\mathrm{mm})$} \\
\cline { 5 - 7 } & $(\%)$ & & 2005 & 2006 & 2005 & 2006 \\
\hline 100 & 100 & 100 & 402 & 458 & 648 & 714 \\
100 & 100 & 75 & 382 & 430 & 628 & 704 \\
100 & 100 & 50 & 356 & 468 & 602 & 676 \\
100 & 75 & 100 & 374 & 433 & 620 & 690 \\
100 & 75 & 75 & 356 & 405 & 602 & 679 \\
100 & 50 & 100 & 336 & 390 & 582 & 646 \\
100 & 50 & 50 & 306 & 400 & 552 & 608 \\
75 & 100 & $100^{\mathrm{a}}$ & 371 & 433 & 617 & 689 \\
75 & 100 & 75 & 341 & 405 & 587 & 679 \\
75 & 75 & 100 & 352 & 409 & 598 & 665 \\
75 & 75 & 75 & 324 & 380 & 570 & 655 \\
50 & 100 & $100^{\mathrm{a}}$ & 338 & 394 & 584 & 650 \\
50 & 100 & 50 & 295 & 404 & 541 & 612 \\
50 & 50 & 100 & 257 & 326 & 503 & 582 \\
50 & 50 & 50 & 211 & 336 & 457 & 544 \\
& & & & & &
\end{tabular}

${ }^{a}$ Indicates primed acclimation treatment (PA) at 50 and 75\% deficits in the early season, respectively.

per growing season). To accomplish differential irrigation amounts among treatments, each irrigation nozzle within a six-row wide swath was fitted with a solenoid (in 2005) or a disc flow control nozzle (in 2006) to deliver the appropriate irrigation percentage around the circumference of the field at that particular radial location. Irrigation quantity treatments were applied at different times during the growing season to coincide with three key peanut developmental stages: early season (0-45 days after planting (dap) affecting root and canopy establishment, flowering, and initial pegging), mid-season (45-90 dap - affecting pod fill, early maturation, and additional limb crop establishment), and late season (90 dap - harvest affecting late pod fill and eventual crop maturation) (Table 1 ). Within each of these 15 irrigation treatments, three replicated plots 6 rows wide and $30.5 \mathrm{~m}$ long were located approximately evenly spaced around the circumference of the 65 ha field. Irrigation treatments will be referred throughout by listing the early-mid-late levels of irrigation: for example the 50-100-50 treatment received 50,100, and 50\% irrigation levels in the early, mid, and late time periods, respectively. This treatment structure included two primed acclimation (PA) treatments: 50 PA and 75 PA which applied 50 and 75\% irrigation during the early period and $100 \%$ during the mid- and late-season periods (50-100-100 and 75-100-100), respectively. Irrigation applied and the total water received, accounting for growing season precipitation, is given for each irrigation treatment in Table 1.

The peanut cultivar, Flavor Runner 458 (FR458), was planted in circular rows across the field on 03 May 2005 and 06 May 2006 at a row spacing of $91 \mathrm{~cm}$ and an inter-seed distance within a row of approximately $5 \mathrm{~cm}$. An important constraint to the system is that it took seven days to apply $38 \mathrm{~mm}$ of irrigation across the entire pivot area. This irrigation amount was the typical amount applied in 2005 and 2006 every 7 days. The irrigation center pivot system was running nearly constantly from stand establishment to near harvest.

\subsection{In-season measurements}

Climatic conditions (wind speed, wind direction, relative humidity, air temperature, and precipitation) were measured and automatically recorded and logged at the field site in 2005 and 2006 using a weather station containing: a Met One 0343-L Windsat 
wind direction and wind speed sensor; a Campbell CS 500 sensor; a LI200X pyranometer; and a TE525 8" tipping bucket rain gauge (Campbell Scientific, Logan, UT, USA). Irrigation amounts were measured in the field in the 50,75 , and $100 \%$ season-long treatments using $\mathrm{HOBO}^{\circledR}$ logging tipping rain buckets (Onset Corporation, Bourne, MA, USA).

Soil moisture was monitored in both years using Watermark Granular Matrix Sensors (Irrometer ${ }^{\circledR}$ Company, Inc.) which measure soil water tension in $\mathrm{kPa}$. Readings were taken by hand approximately 3 times a week during the entire growing season in three of the irrigation treatments: 100-100-100, 75-75-75, and 50-50-50. Due to the constraints of measuring soil moisture in all of the 15 irrigation treatments, these three treatments were chosen to provide quantification of the effect of fullseason DI schemes on soil moisture in comparison to the control (100-100-100). For conversion of readings to volumetric water content (VWC), the relationship between soil water content and soil water potential was determined. Replicate soil samples were collected from 20,40, and $60 \mathrm{~cm}$ deep samples corresponding with Watermark sensor depth. Mean soil bulk density $\left(\rho_{\text {bulk }}\right)$ was determined using 3 soil volumes $(10,15,20 \mathrm{ml})$ from each depth and calculated to be $1.27 \mathrm{~g} \mathrm{~cm}^{-3}$. Porosity $(\varepsilon)$ was calculated as $1-\left(\rho_{\text {bulk }} / \rho_{\text {solid }}\right)=1-(1.27 / 2.6)=0.51$, where $\rho_{\text {solid }}$ (particle density) $=2.6 \mathrm{~g} \mathrm{~cm}^{-3}$. A moisture release curve was generated using a WP4 Dewpoint Potentiameter (Decagon, USA). The moisture release curve yielded a power function equation $\left(y=0.0779 x^{-1.0225}\right)$ where $y=\Psi_{\text {soil }}$ (matric potential of the soil) and $x=$ VWC. Watermark data were converted from $\mathrm{kPa}$ to MPa and VWC was calculated and expressed as percent.

In 2006, additional in-season crop measurements were conducted to document the differential effect of irrigation on crop traits, concentrating primarily on comparisons among the two fullseason DI treatments (50-50-50,75-75-75), and the fully irrigated (100-100-100) treatment. Logged infra-red thermometers (IRTS-P sensor; Apogee Instruments Inc., Logan, UT) measured canopy surface temperatures. NDVI (Normalized Difference Vegetation Index) was measured using the Greenseeker sensor (NTech Industries, Ukiah, CA, USA), with two additional treatments measured in comparison to the 100-100-100, 75-75-75, and 50-50-50 treatments: 50 PA and 75 PA. Root growth and architecture were assessed using mini-rhizotrons installed in three locations in the field parallel to the row direction: directly in the row, $10.2 \mathrm{~cm}$ off the row, and $45.7 \mathrm{~cm}$ off the row (exactly between two rows). Digital images were taken using the Bartz mini-rhizotron camera and image acquisition system (Bartz Technology Corporation, Carpinteria, CA, USA) spaced throughout the season on 11 May, 30 June, 10 August and 4 October, 2006. For each mini-rhizotron tube, an image was taken every $13.5 \mathrm{~mm}$ at the top of each tube along its length. Images were analyzed with the WinRHIZO TRON software (Régent Instruments Inc., Canada) which included measurements of root length, density, surface area, etc. for each digital frame taken along the tube. Data for root length were visualized with SigmaPlot (Systat Software Inc., San Jose, CA, USA) by combining all three locations into one image that illustrated the overall depth and lateral development of the root system.

\subsection{Yield: quantity and quality}

Plots were dug using a commercial peanut digger on approximately 14 October in both years. Inverted rows were allowed to dry in the windrow and were harvested (threshed) on 09 November 2005 and 04 November 2006. Peanut yield and grade were calculated based on sample plots of $30.7 \mathrm{~m}$ long by 2 rows wide. Plots were randomly located within each of the three field replications for each irrigation treatment in the field. Upon harvest, sample bags were weighed and a 1-kg moisture subsample removed from the composite sample of each plot. Field weight and moisture content were used to express yield on a hectare basis, at a standard marketable moisture content of $10 \%$. A second $3-\mathrm{kg}$ subsample was removed from each composite harvested plot for grade determination. Grade samples were allowed to further dry to $7 \%$ moisture before processing through standard USDA grading procedures to determine total sound mature kernels (TSMK) as presented herein (USDA, 1993). A full grade analysis was done, however only TSMK results are presented as they best represent peanut quality and maturity. Additionally, yield and grade were combined to obtain gross plot value to estimate economic response of irrigation treatments. A standard USDA peanut marketing loan value ( $\left.\$ 876 \mathrm{ha}^{-1}\right)$ was assumed to calculate value per ton based on grade factors, which was then used to calculate value per plot based on the plot yield. Furthermore, irrigation costs were calculated based on a $\$ 9.72 \mathrm{ha}^{-1} \mathrm{~cm}^{-1}$ estimated cost for west Texas. Subsequently, the cost of irrigation for each plot was subtracted from the gross value per plot to give an economic crop value inclusive of differences in irrigation. Full net returns above costs were not calculated assuming all other crop inputs were equal across treatments.

\subsection{Statistical analyses}

Yield, grade, and economic values were analyzed using Generalized Linear Models (SAS Institute Inc., Cary, NC). Year and irrigation were tested as main effects and for their interaction. Where appropriate, Fisher's LSD test of means was used to describe difference in treatments. For the in-season crop measurements of NDVI and root measurements, analysis of variance (ANOVA) was performed with appropriate factors for each measurement type and Tukey's multiple comparisons test were used to separate means when factors were significantly different (SAS JMP, SAS Institute Inc., Cary, NC).

\section{Results}

\subsection{Impact on peanut yield and grade}

Yield, grade, and economic return based on costs of irrigating showed a strong year effect thus data are presented by year. Average yields in all fifteen irrigation treatments exceeded the Texas state average peanut yield in both years which were 4203 and $4147 \mathrm{~kg} \mathrm{ha}^{-1}$ in 2005 and 2006 respectively (NASS, 2007). In 2005, the fully irrigated control treatment, 100-100-100, yielded the highest but was not significantly different from the $50-50-100$ or the 50-100-100 (50 PA) treatments that yielded 94 and $90 \%$, respectively, of the control (Table 2 ). The $50-50-50$ full season DI treatment yielded only $74 \%$ of the control but the lowest yield was seen in the $50-100-50$ treatment that was $61 \%$ of the control. While the yield of the 50 PA treatment was not different than the control, the 75 PA was lower with $80 \%$ of the control. Results were slightly different for yield in 2006: the highest yields were seen in the $100-100-50$ and $100-50-100$ treatments which yielded 111 and $104 \%$ in comparison to the control (Table 2). Among the DI and RDI treatments, the 75-75-75, 50 PA, and 75 PA yielded 100, 101, and $98 \%$, respectively, of the control showing there was no impact on yield by moderate decreases in water application in 2006. The lowest yields were in the 50-50-50 which was $90 \%$ of the control. Grades were uniform in both 2005 and 2006 and ranged from 81 to 83 in 2005 with no significant differences among the 15 irrigation treatments (Table 3 ). In 2006, only the most severe deficit treatment, 50-50-50, was significantly lower in grade (77) than the top four treatments (80-81) but was not significantly different than the fully irrigated control (79). 
Table 2

Peanut yield by irrigation treatment in the west Texas field site in 2005 and 2006. Yields are presented as a percentage of the full irrigation (100-100-100) treatment.

\begin{tabular}{lccll}
\hline Early-season & Mid-season & Late season & 2005 & 2006 \\
\hline \multicolumn{3}{c}{$(\%)$} & \multicolumn{3}{c}{$\begin{array}{l}\text { Percent }{ }^{\mathrm{a}} \text { of full } \\
\text { irrigation }^{\mathrm{b}}\end{array}$} \\
\hline 100 & & & $100 \mathrm{a}$ & $100 \mathrm{~b}$ \\
100 & 100 & 100 & $79 \mathrm{bc}$ & $98 \mathrm{bc}$ \\
100 & 100 & 75 & $72 \mathrm{~cd}$ & $111 \mathrm{a}$ \\
100 & 100 & 50 & $82 \mathrm{~b}$ & $97 \mathrm{c}$ \\
100 & 75 & 100 & $82 \mathrm{~b}$ & $91 \mathrm{~cd}$ \\
100 & 75 & 75 & $63 \mathrm{de}$ & $104 \mathrm{ab}$ \\
100 & 50 & 100 & $68 \mathrm{~d}$ & $95 \mathrm{~cd}$ \\
75 & 50 & 50 & $80 \mathrm{bc}$ & $98 \mathrm{bc}$ \\
75 & 100 & $100^{\mathrm{c}}$ & $81 \mathrm{bc}$ & $99 \mathrm{~b}$ \\
75 & 100 & 75 & $69 \mathrm{~d}$ & $99 \mathrm{~b}$ \\
75 & 75 & 100 & $85 \mathrm{~b}$ & $100 \mathrm{~b}$ \\
50 & 75 & 75 & $90 \mathrm{ab}$ & $101 \mathrm{~b}$ \\
50 & 100 & $100^{\mathrm{c}}$ & $61 \mathrm{e}$ & $102 \mathrm{~b}$ \\
50 & 100 & 50 & $94 \mathrm{ab}$ & $95 \mathrm{c}$ \\
50 & 50 & 100 & $74 \mathrm{c}$ & $90 \mathrm{~d}$ \\
\hline
\end{tabular}

a Percentages followed by the same lowercase letter are not statistically different according to Fisher's Protected LSD at $P=0.05$.

b Full irrigation was the farmer-maintained standard of 100-100-100; actual yield values $2005=7423 \mathrm{~kg} \mathrm{ha}^{-1}, 2006=5957 \mathrm{~kg} \mathrm{ha}^{-1}$.

${ }^{c}$ Indicates primed acclimation treatment (PA) at 50 and $75 \%$ deficits in the early season, respectively.

\subsection{Environmental variability between years}

Total precipitation received by the field was nearly identical in 2005 and 2006: $246 \mathrm{~mm}$. However rainfall patterns differed between years showing some significant rainfall events and overall greater amounts in the early season of 2005 ( 2 events $\geq 25 \mathrm{~mm}$ in May) than in 2006 (Fig. 1). Differences between years were also seen during the mid- and late-seasons with higher levels of precipitation in 2006 than 2005 during the pod fill and maturation periods from approximately August through harvest (Fig. 1).

Ambient air temperature patterns differed as well between 2005 and 2006. Maximum air temperatures tended to be higher throughout the season in 2006 than in 2005 with the exception of the first three weeks in September, often reaching levels between 37 and $40^{\circ} \mathrm{C}$ (Fig. 2). In contrast, minimum temperatures trended around $20^{\circ} \mathrm{C}$ in both years. Average air temperatures were higher overall from planting to 30 August in 2006 as compared to 2005 (Fig. 2).

Table 3

Peanut grade by irrigation treatment in west Texas field site in 2005 and 2006.

\begin{tabular}{ccclc}
\hline Early-season & Mid-season & Late season & 2005 & 2006 \\
\hline$(\%)$ & & & Percent $^{\mathrm{a}}$ & TSMK $^{\mathrm{b}}$ \\
\hline 100 & 100 & 100 & $82 \mathrm{a}$ & $79 \mathrm{ab}$ \\
100 & 100 & 75 & $83 \mathrm{a}$ & $80 \mathrm{a}$ \\
100 & 100 & 50 & $82 \mathrm{a}$ & $79 \mathrm{ab}$ \\
100 & 75 & 100 & $82 \mathrm{a}$ & $79 \mathrm{ab}$ \\
100 & 75 & 75 & $82 \mathrm{a}$ & $80 \mathrm{a}$ \\
100 & 50 & 100 & $82 \mathrm{a}$ & $79 \mathrm{ab}$ \\
100 & 50 & 50 & $82 \mathrm{a}$ & $79 \mathrm{ab}$ \\
75 & 100 & 75 & $81 \mathrm{ab}$ & $79 \mathrm{ab}$ \\
75 & 100 & 100 & $82 \mathrm{a}$ & $79 \mathrm{ab}$ \\
75 & 75 & 75 & $82 \mathrm{a}$ & $79 \mathrm{ab}$ \\
75 & 75 & $100^{\mathrm{c}}$ & $83 \mathrm{a}$ & $80 \mathrm{a}$ \\
50 & 100 & 50 & $81 \mathrm{ab}$ & $81 \mathrm{a}$ \\
50 & 100 & 100 & $81 \mathrm{ab}$ & $79 \mathrm{ab}$ \\
50 & 50 & 50 & $82 \mathrm{a}$ & $77 \mathrm{ab}$ \\
50 & 50 & & &
\end{tabular}

a Percentages followed by the same lowercase letter are not statistically different according to Fisher's Protected LSD at $P=0.05$.

b TSMK - total sound mature kernels.

c Indicates primed acclimation treatment (PA) at 50 and 75\% deficits in the early season, respectively.
The presence of temperature stress in the crop in 2006 was confirmed from the plant canopy temperatures logged during that year (Fig. 3). Plant canopy temperatures exhibited characteristic seasonal variability but often reached levels above $28^{\circ} \mathrm{C}$ between 20 May through 10 August 2006, exceeding an identified stress threshold level of $27^{\circ} \mathrm{C}$ as described by Mahan et al. (2005) for peanut. Variability among irrigation treatments became apparent by approximately 03 July and was punctuated by the highest canopy temperatures occurring in the 75-75-75 deficit treatment from 29 July until harvest.

Differences in soil VWC across the season in 2005 and 2006 reflected variability in the precipitation patterns between the two years and likely contributed to alterations in the magnitude of yield variability among treatments (Figs. 4 and 5). At the 20 and $41 \mathrm{~cm}$ depths, soil moisture remained elevated in 2005 during mid-season (approximately 23 July to 23 August, reflective of large precipitation events during this period) when pod fill was at peak levels. In contrast, 2006 showed higher VWC levels than 2005 only at the $61 \mathrm{~cm}$ depth, from approximately 15 August through harvest, again following large and sustained precipitation events. Further, differences among the three irrigation treatments monitored were evident as well (Figs. 4 and 5) in both 2005 and 2006, and showed expected patterns of increased VWC in the 100-100-100 treatment in comparison to both deficit irrigation treatments, 50-50-50 and 75-75-75, at all three depths.

\subsection{Effect of rainfall and RDI on crop response}

When quantifying reproductive output directly by counting flowers, pegs, and pods per plant in 2006, the effect of drought stress could be clearly seen (Fig. 6). The number of flowers per plant in the 50-50-50 showed quite a different pattern than the $75-75-75$ or $100-100-100$ treatments: flower production peaked in late June to early July while for the other treatments, number of flowers per plant peaked in late July. In contrast, peg production was more similar for the two DI treatments (50-50-50, 75-75-75) which showed a peak number per plant by mid-July while the 100-100-100 number of pegs did not peak until early August. Pod production was decreased for the 50-50-50 treatment in comparison to the other two treatments over most of the late season which is in line with this treatment's overall lower yield at harvest.

NDVI in 2006 by mid-season was able to distinguish differences between the most severe drought stressed treatment (50-50-50) and the 75 PA treatment (Fig. 7). By September, the two PA treatments (75-100-100 and 50-100-100) had the highest NDVI values, with the 50 PA treatment significantly above the 50-50-50 treatment $(F=3.9 ; P$-value $=0.0109)$. To understand the dynamics of the response in NDVI in more detail, we compared NDVI values directly after an irrigation (1 day post irrigation - $1 \mathrm{DPI}$ ) and just prior to the next irrigation ( 7 days post irrigation - 7 DPI) in August 2006, the time period when reproductive load and heat and moisture stress would be maximal. At 1 DPI, when the soil VWC levels were maximal and stress should be at a minimum, all irrigation treatments showed equivalent NDVI levels. By 7 DPI (when stress was maximal), a decrease in NDVI was noted in the most severe deficit treatment (50-50-50), with the 100-100-100, 75-75-75, and PA treatments showing minimal decreases, indicating a better tolerance of intensifying drought conditions in these treatments (Fig. 8).

Root development and architecture over time clearly showed differences in water availability between the 50-50-50 and 100-100-100, as measured using mini-rhizotrons in 2006. Irrigation treatments had significant impacts on all root parameters measured and the interaction of irrigation with depth indicated a change in root architecture through the soil profile related to water application and possibly plant available water at those depths (Table 5). Examining the root development patterns within the 
2005

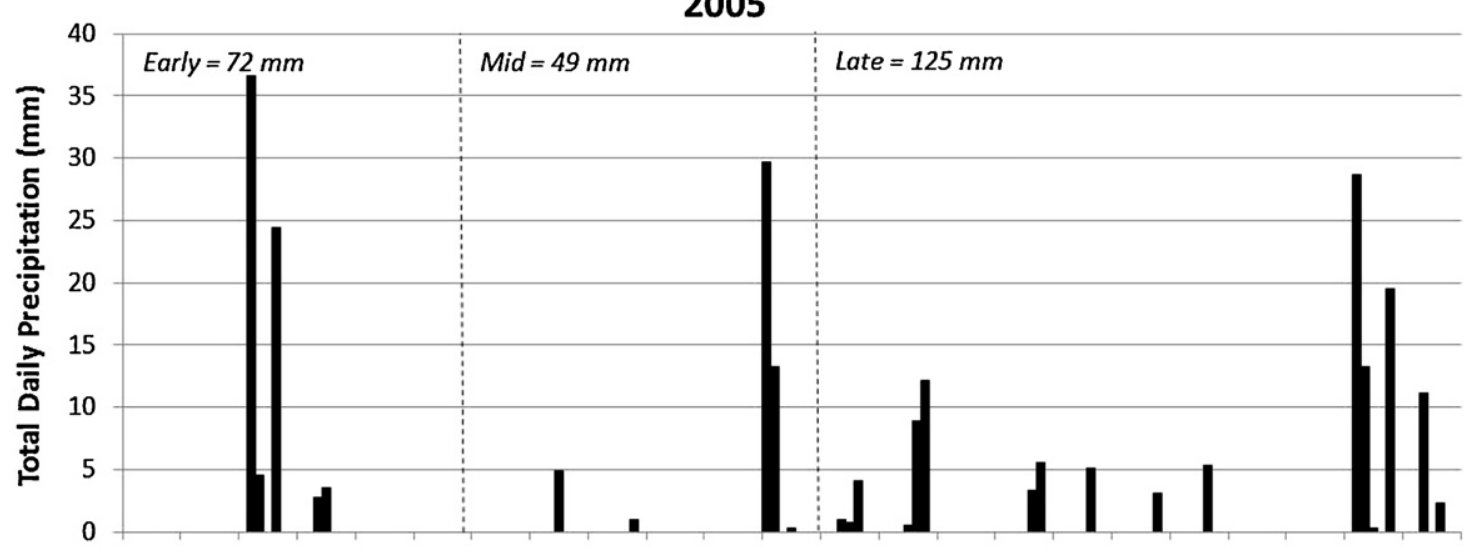

2006

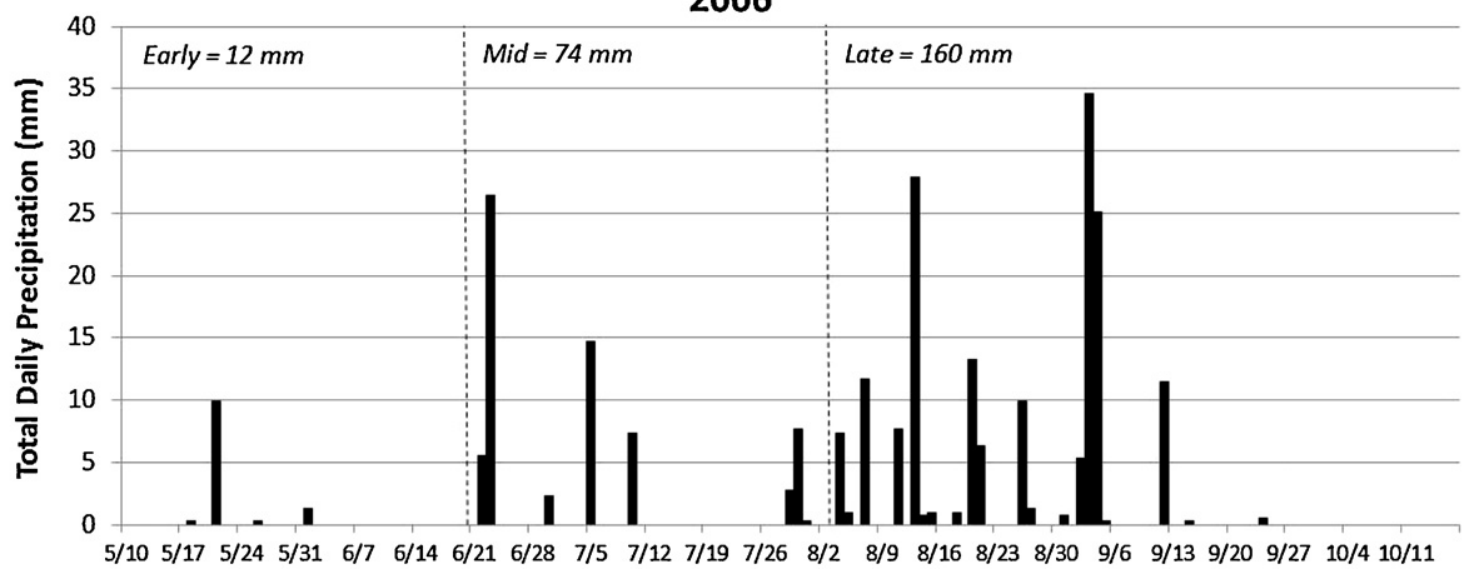

Fig. 1. Total daily precipitation in 2005 and 2006. The total received during the growing season was nearly identical in both years: 246 mm.

Table 4

Peanut net value less irrigation costs for 2005 and 2006.

\begin{tabular}{lccll}
\hline Early-season & Mid-season & Late season & 2005 & 2006 \\
\hline & $(\%)$ & & & $\$ h^{-1} \mathrm{a}$ \\
\hline 100 & 100 & 100 & $2812 \mathrm{a}$ & $1836 \mathrm{bc}$ \\
100 & 100 & 75 & $2207 \mathrm{cdef}$ & $1856 \mathrm{bc}$ \\
100 & 100 & 50 & $1969 \mathrm{defg}$ & $2161 \mathrm{a}$ \\
100 & 75 & 100 & $2273 \mathrm{cde}$ & $1806 \mathrm{bc}$ \\
100 & 75 & 75 & $2310 \mathrm{~cd}$ & $1721 \mathrm{~d}$ \\
100 & 50 & 100 & $1694 \mathrm{~g}$ & $1992 \mathrm{abc}$ \\
100 & 50 & 50 & $1937 \mathrm{efg}$ & $1845 \mathrm{bc}$ \\
75 & 100 & $100^{\mathrm{b}}$ & $2171 \mathrm{cdef}$ & $1822 \mathrm{bc}$ \\
75 & 100 & 75 & $2281 \mathrm{cde}$ & $1884 \mathrm{abc}$ \\
75 & 75 & 100 & $1869 \mathrm{fg}$ & $1885 \mathrm{abc}$ \\
75 & 75 & 75 & $2442 \mathrm{bc}$ & $1949 \mathrm{abc}$ \\
50 & 100 & $100^{\mathrm{b}}$ & $2511 \mathrm{abc}$ & $1973 \mathrm{abc}$ \\
50 & 100 & 50 & $1693 \mathrm{~g}$ & $2015 \mathrm{ab}$ \\
50 & 50 & 100 & $2724 \mathrm{ab}$ & $1840 \mathrm{bc}$ \\
50 & 50 & 50 & $2182 \mathrm{cdef}$ & $1768 \mathrm{bc}$ \\
\hline
\end{tabular}

a Percentages followed by the same lowercase letter are not statistically different according to Fisher's Protected LSD at $P=0.05$.

b Indicates primed acclimation treatment (PA) at 50 and 75\% deficits in the early season, respectively.

row and extending laterally at $10 \mathrm{~cm}$ and $46 \mathrm{~cm}$ off the row, and throughout the soil profile from the surface to $1 \mathrm{~m}$ depth, interesting differences among water application rates are evident (Fig. 9). Overall rooting depth was enhanced in the 50-50-50 treatment in comparison to the 100-100-100 treatment as well as root proliferation at the middle soil depths (approximately $40-70 \mathrm{~cm}$ ). Interestingly, these rooting pattern differences were clear at the first measurement date in June and persisted until crop senescence in October. Root production in the full irrigation treatment was generally decreased and concentrated at more shallow depths in comparison to the more severely stressed 50-50-50 treatment.

\section{Discussion}

The yield and grade levels found in this study indicate that some of the tested DI and RDI schemes have promise for conserving water while maintaining production levels across years including the 50 PA, 75 PA, and 75-75-75. By utilizing reduced irrigation schemes that maintain yield and quality, production may be sustained in this semi-arid region even with declining water resources. These results are in contrast to a recent study in peanut that found decreased yields in four reduced irrigation schemes timed to certain developmental periods in Egypt (Kheira, 2009). However, the current study utilized additional RDI schemes and variable deficit levels not tested in Kheira (2009) which, in the current study, were found to be successful. The success or failure of DI applied all season may lie in the levels of deficits used. Moderate levels of DI, as was the situation for the 75-75-75 treatment, have shown promise in other crops (Costa et al., 2007; Geerts and Raes, 2009; Stewart et al., 2011), and this treatment was able to maintain yield equal to the fully irrigated treatment in one year of the study. However, the RDI strategies utilizing early season water deficits during vegetative stages, or PA as the current study has defined it, were more consistent in maintaining optimal yields across the two years. RDI has been found to be successful for a range of crops (Kang et al., 2000, 2002; Zhang et al., 2006; and references within Geerts and 


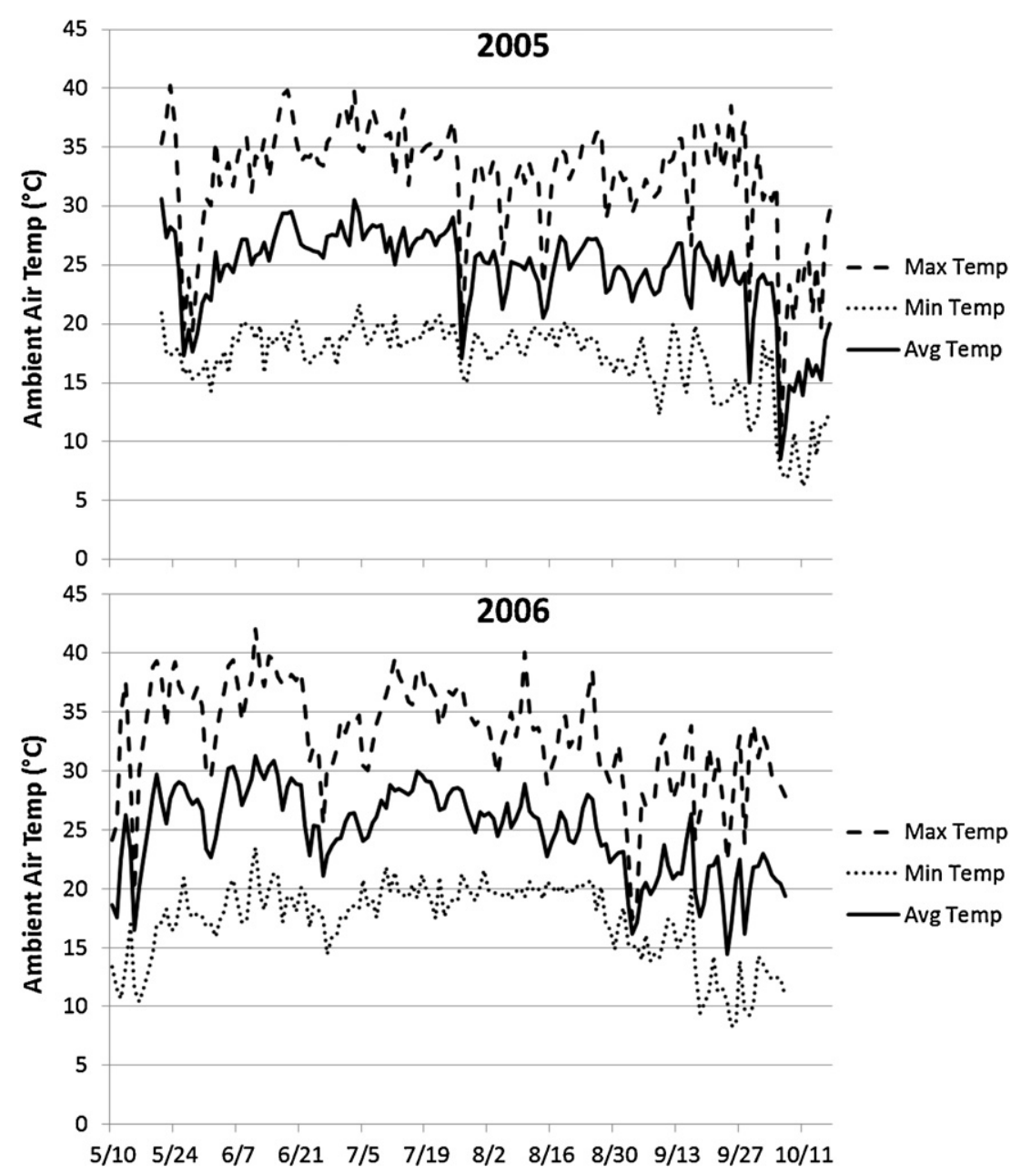

Fig. 2. Maximum, minimum, and average daily ambient air temperatures in 2005 and 2006 for the research field site in west Texas.

Raes, 2009). Even more important are results found for peanut: there is evidence that water deficits imposed during early vegetative stages have the potential to at least maintain, and in some cases, even increase yield (Ong, 1984; Rao et al., 1985); while the impacts of drought are most severe when it occurs during peak reproduction (Rao et al., 1985; Stansell and Pallas, 1985; Wright et al., 1991). Another primary advantage of PA systems is the potential of early season moderate drought stress to acclimate the crop to better withstand mid- and late-season drought stress (Flexas et al., 2006).
The economic viability of the PA concept can be seen by the comparisons in net value ( $\$ / \mathrm{ha}$ ) which take into account yield, grade, and the cost of pumping variable amounts of water among treatments (Table 4). Net value for the 50 PA treatment was consistently equal to the 100-100-100 treatment in both years indicating that water savings could be realized by decreasing amounts of early season water applications with no concomitant drop in economic return to the grower. The 75 PA treatment was less consistent in value across years in comparison to the control treatment with a lower value in 2005 but equal in 2006 to the 100-100-100. This

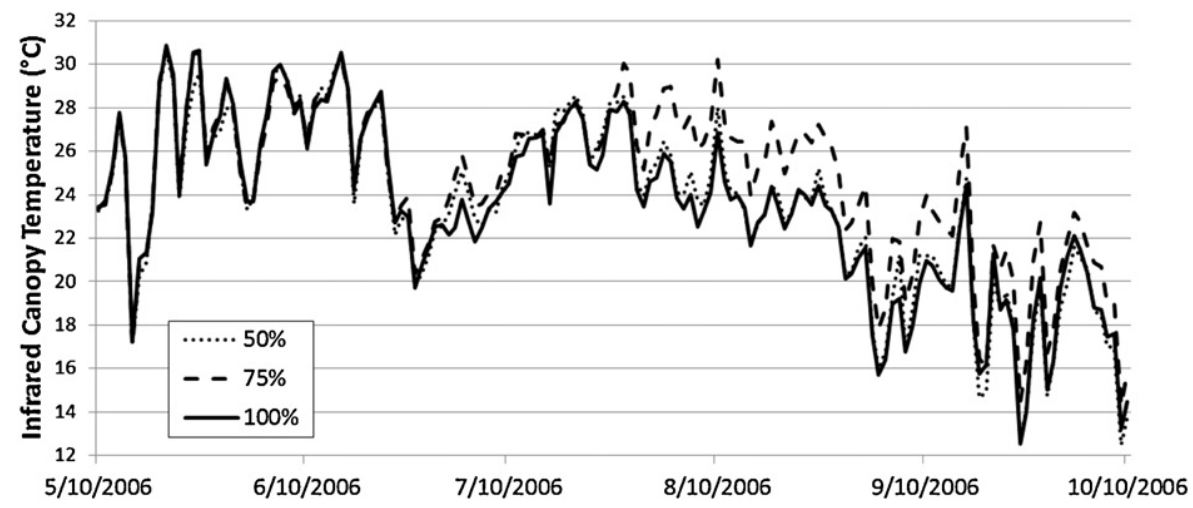

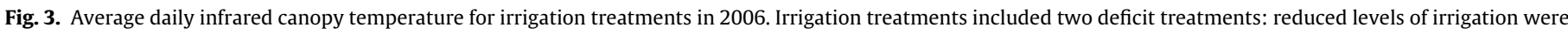
applied all season, 50-50-50 and 75-75-75 (50 and 75\%), and the fully irrigated treatment, 100-100-100 (100\%). 
Table 5

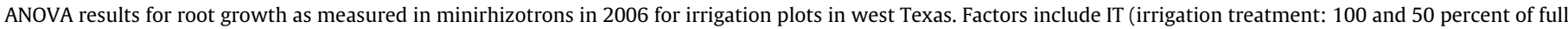

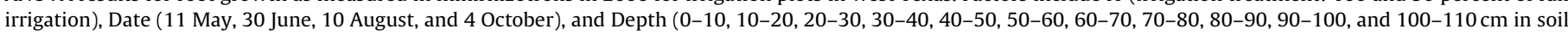
depth) and all two-way interactions.

\begin{tabular}{|c|c|c|c|c|c|c|c|c|c|}
\hline Trait: & df & $\begin{array}{l}\text { Avg root } \\
\text { length } \\
\text { F ratio }\end{array}$ & $\begin{array}{l}\text { Sum root } \\
\text { length } \\
F \text { ratio }\end{array}$ & $\begin{array}{l}\text { Avg surface } \\
\text { area } \\
\text { F ratio }\end{array}$ & $\begin{array}{l}\text { Sum surface } \\
\text { area } \\
F \text { ratio }\end{array}$ & $\begin{array}{l}\text { Avg root } \\
\text { diameter } \\
F \text { ratio }\end{array}$ & $\begin{array}{l}\text { Sum root } \\
\text { diameter } \\
\text { F ratio }\end{array}$ & $\begin{array}{l}\text { Avg root tips } \\
F \text { ratio }\end{array}$ & $\begin{array}{l}\text { Sum root tips } \\
F \text { ratio }\end{array}$ \\
\hline \multicolumn{10}{|l|}{ Factors } \\
\hline IT & 1 & $11.6^{\mathrm{b}}$ & $11.4^{\mathrm{b}}$ & $22.5^{c}$ & $22.0^{c}$ & $30.5^{c}$ & $31.0^{c}$ & $13.5^{\mathrm{b}}$ & $12.9^{\mathrm{b}}$ \\
\hline Date & 3 & $21.4^{\mathrm{c}}$ & $20.7^{c}$ & $19.1^{c}$ & $18.3^{c}$ & $36.8^{c}$ & $37.6^{c}$ & $23.9^{c}$ & $23.4^{\mathrm{c}}$ \\
\hline Depth & 10 & $9.4^{\mathrm{c}}$ & $9.5^{c}$ & $10.3^{c}$ & $10.6^{c}$ & $17.8^{\mathrm{c}}$ & $20.5^{c}$ & $8.9^{c}$ & $9.3^{c}$ \\
\hline IT $\times$ Date & 3 & 1.6 & 1.5 & $4.2^{\mathrm{a}}$ & $4.0^{\mathrm{a}}$ & $6.2^{\mathrm{b}}$ & $5.9^{\mathrm{b}}$ & 1.5 & 1.5 \\
\hline IT $\times$ Depth & 10 & $4.4^{\mathrm{c}}$ & $4.4^{\mathrm{c}}$ & $4.9^{c}$ & $4.9^{\mathrm{c}}$ & $4.4^{\mathrm{c}}$ & $4.4^{\mathrm{c}}$ & $4.1^{\mathrm{c}}$ & $4.2^{c}$ \\
\hline Date $\times$ Depth & 30 & $1.6^{\mathrm{a}}$ & $1.6^{\mathrm{a}}$ & $1.8^{\mathrm{a}}$ & $1.7^{\mathrm{a}}$ & $2.9^{c}$ & $3.0^{c}$ & $1.6^{\mathrm{a}}$ & $1.6^{\mathrm{a}}$ \\
\hline
\end{tabular}

a $P<0.05$.

b $P<0.001$.

c $P<0.0001$.

indicates that the crop may actually be benefitting more by an increased level of stress restricted to the early, vegetative stage. The detrimental effects of drought imposed during later developmental stages were evident in economic returns as seen in 2005 , in particular. All of the treatments that incorporated either 50 or $75 \%$ levels in the late season during that year, with the exception of the 75-75-75 treatment, were significantly lower in net value than the fully irrigated control.

Variability between years in yield and net value can partially be linked to supplemental rainfall patterns and to other

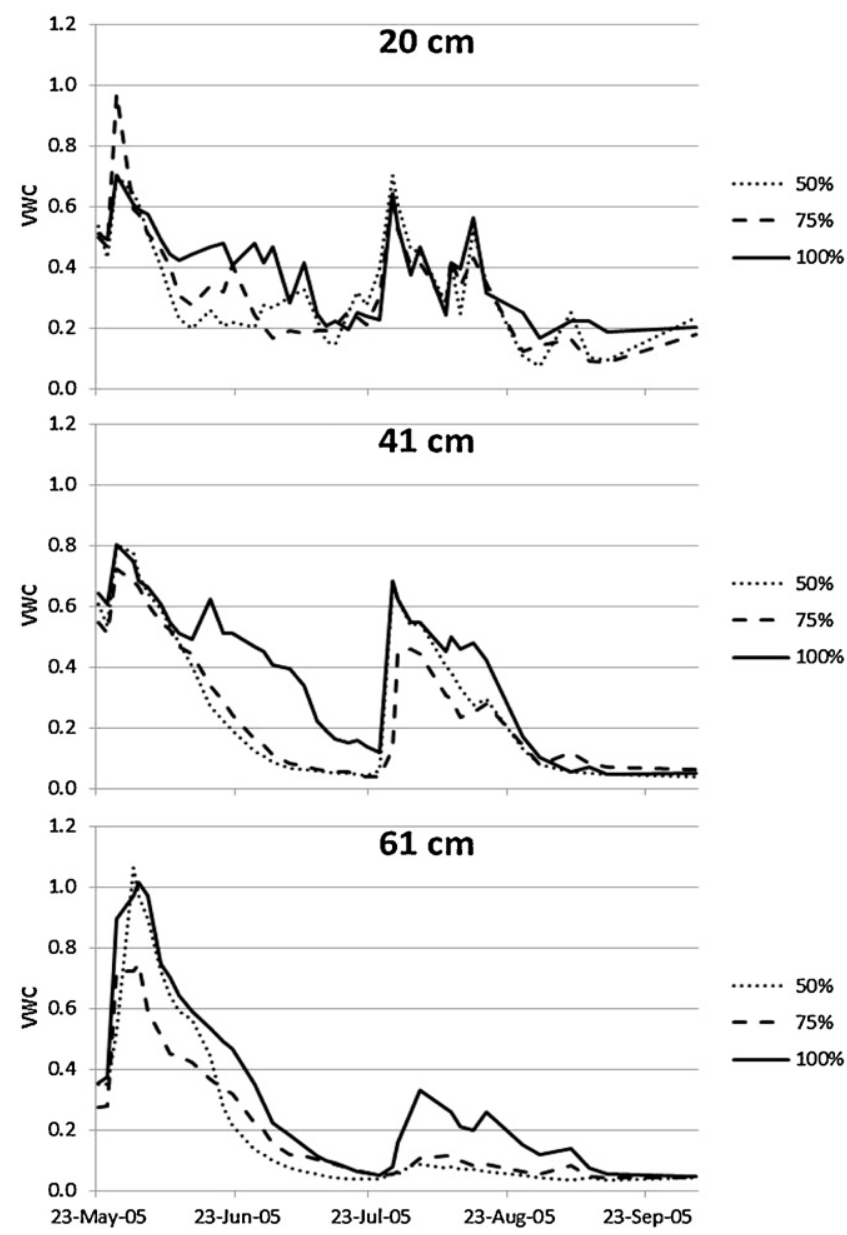

Fig. 4. Volumetric soil water (VWC) content of soils in west Texas in 2005. Measurements were taken in 3 irrigation treatments: reduced levels of irrigation applied all season, 50-50-50 and 75-75-75 (50 and 75\%), and the fully irrigated treatment, 100-100-100 (100\%). Measurements were taken at 3 depths: 20, 41, and $61 \mathrm{~cm}$. environmental conditions which modified the effects of reduced irrigation levels during the growing season. In particular, the extremely low levels of precipitation in the early season of 2006 during peak flowering and early pod initiation likely contributed to the overall decreased yields and low magnitude of differences among treatments (Table 2). However, high levels of late-season rainfall in 2006 likely enhanced yield levels in treatments that utilized deficit levels of irrigation during this period, and may explain why the 100-100-50 treatment yielded above the fully

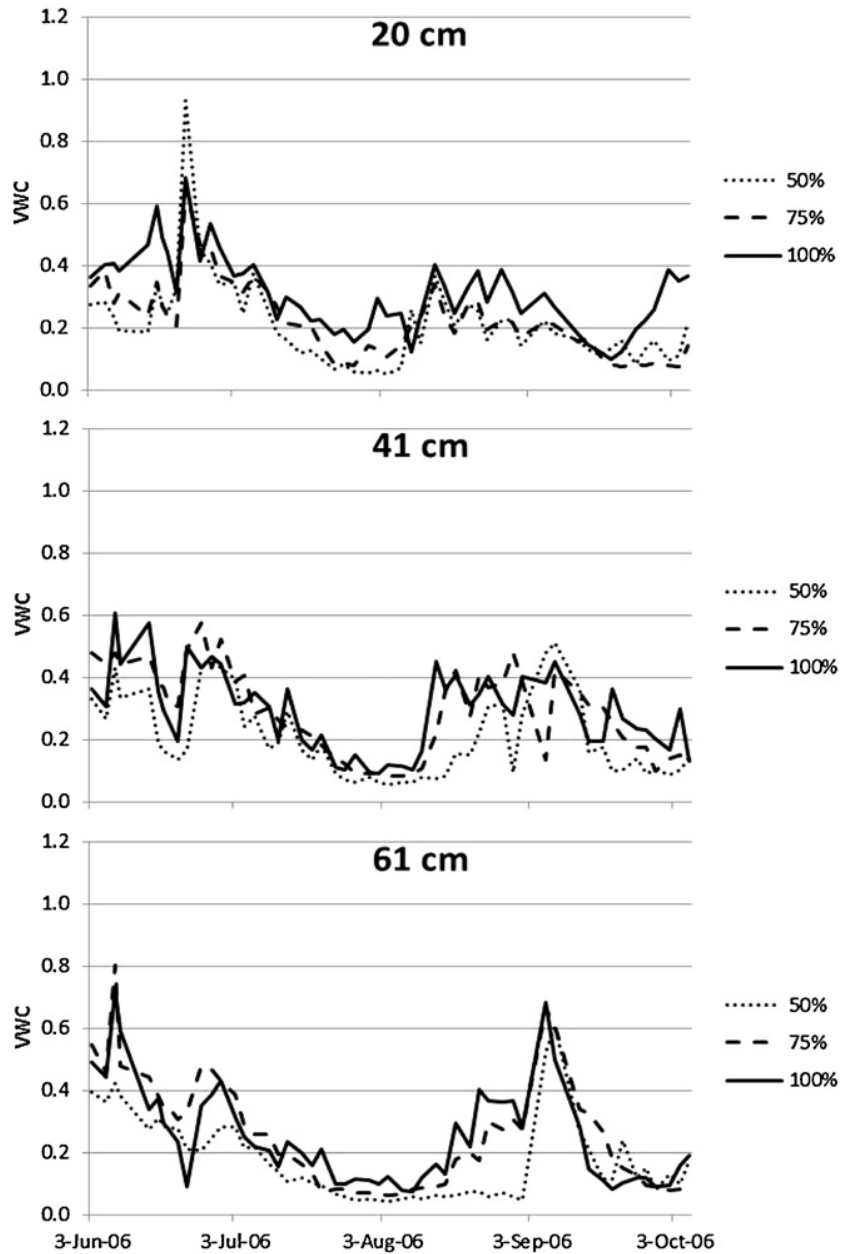

Fig. 5. Volumetric soil water (VWC) content of soils in west Texas in 2006. Measurements were taken in 3 irrigation treatments: reduced levels of irrigation applied all season, 50-50-50 and 75-75-75 (50 and 75\%), and the fully irrigated treatment, 100-100-100 (100\%). Measurements were taken at 3 depths: 20,41 , and $61 \mathrm{~cm}$. 

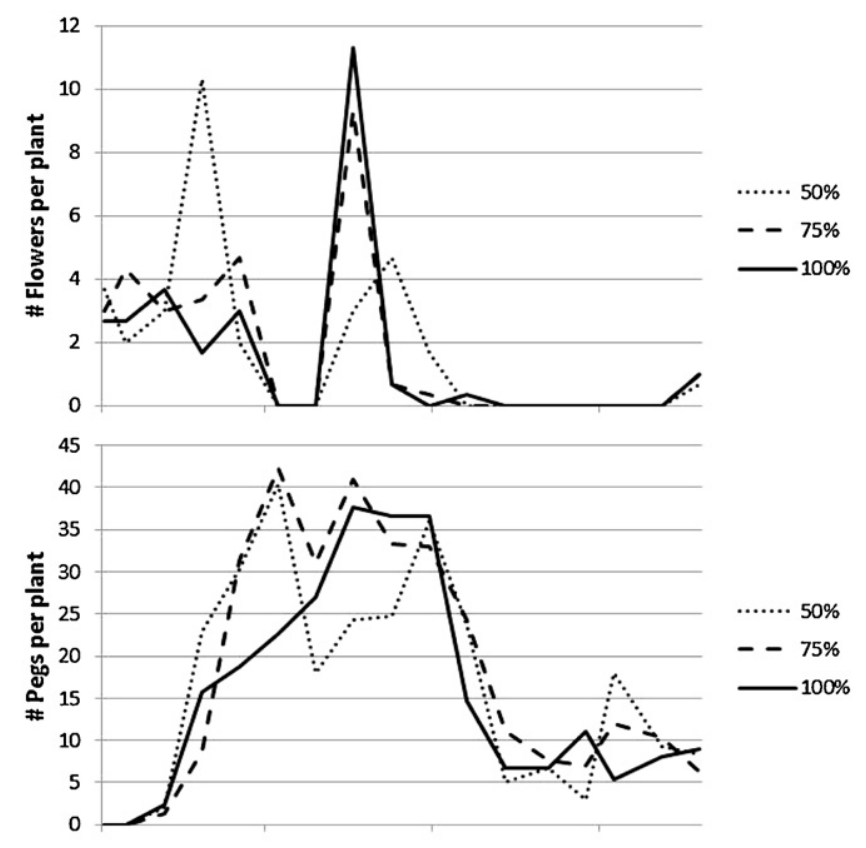

a.

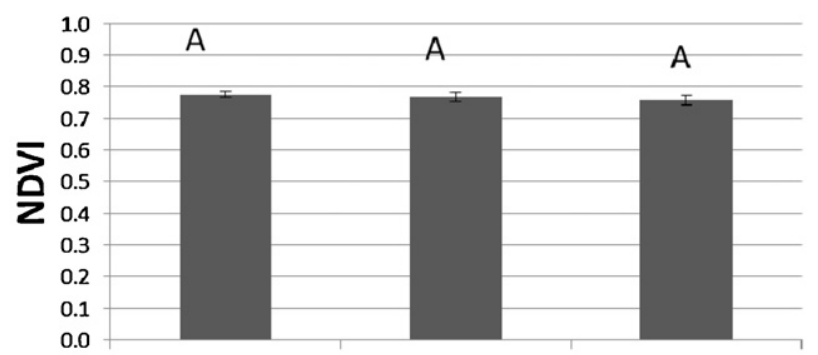

b.

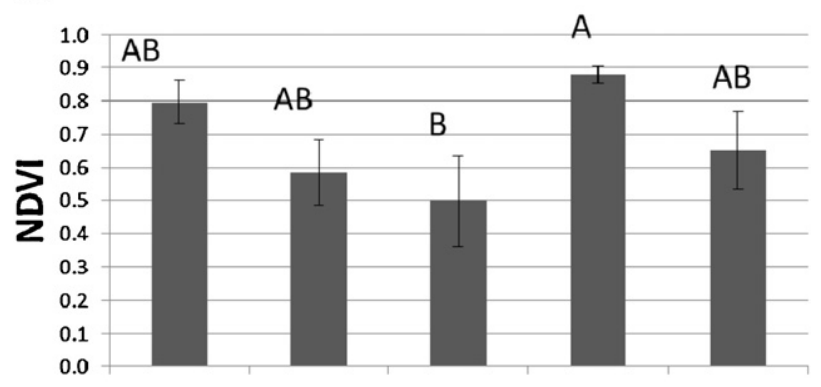

C.
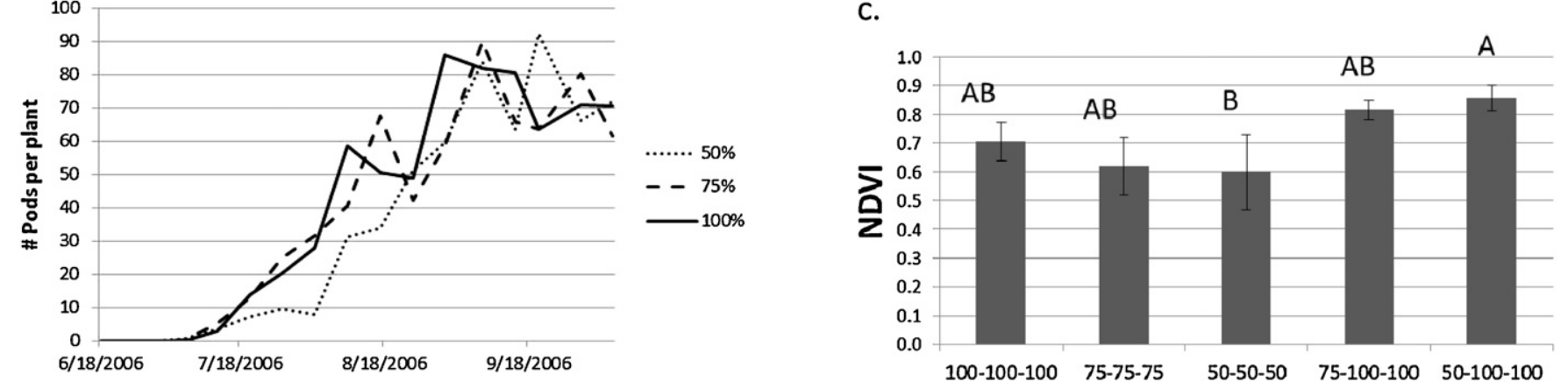

Fig. 6. Flower, peg, and pod numbers per plant for the field site in west Texas across the growing season in 2006. Irrigation treatments included two deficit treatments: reduced levels of irrigation were applied all season 50-50-50 and 75-75-75 (50 and $75 \%$ ), and the fully irrigated treatment, 100-100-100 (100\%).

irrigated control in that year. Combining the patterns of seasonal precipitation, air temperatures, and soil moisture, it is likely that temperature and soil moisture stress were higher in 2006 than in 2005 , and much of this stress was timed to the critically sensitive early flowering, pegging and pod initiation periods. This is likely the cause of the overall reduced yields across all irrigation treatments in 2006 as compared to 2005.

Monitoring in-season crop response can better elucidate mechanisms behind the final yield differences among irrigation treatments. This study monitored patterns of reproduction, overall crop stress through NDVI, and changes in root architecture that would influence water availability to the crop. Following production of individual reproductive structures (flowers, pegs, and pods) is helpful in identifying when stress has reached critical levels for peanut. It is known that water deficits often do not delay peanut flower production (Boote and Ketring, 1990 ), and in this study, it appears that mild stress (50\% in the early season) may actually have accelerated the transition from the vegetative to flowering stage. Further, peg production was enhanced and accelerated in both DI treatments (50-50-50, 75-75-75) above the fully irrigated treatment. This augmentation of reproductive output can lead to a more uniform flowering and pod set which is desirable to avoid inconsistent crop maturity later in the growing season.

Fig. 7. NDVI measurements for the Texas field site; a. June 29, 2006; b. August 7 2006; c. September 20, 2006. All measurements were taken at mid-day.

One of the key questions in the implementation of any DI or RDI (such as the PA treatments) in different production regions with varying climatic conditions is how to determine and monitor the appropriate stress level in the crop to avoid yield losses. Measurement of NDVI is a possible candidate for monitoring drought stress in peanut and other crops (Mahey et al., 1991; Peñuelas et al., 1993, 1994; Peñuelas and Inoue, 1999). As far as the utility of NDVI for calibrating an appropriate stress level in this study, NDVI was successful at distinguishing the most drought stressed treatment (50-50-50) from the other more highly irrigated treatments, but could not distinguish the other DI level (75-75-75). Differences in NDVI were also not apparent until later in the season and only after several days post-irrigation. These limitations would make the utility of this sensor at distinguishing more fine-scale differences among plant stress levels constrained to particular applications.

A very important trait that could allow the crop in DI and RDI treatments to better withstand drought stress is root architecture. A unique aspect of the current study is the quantification of root responses season-long to DI. Striking differences were found between $50 \%$ DI and full irrigation. Roots were not only deeper but were in higher quantities at mid soil depths (approximately 40-70 cm depths) in the 50-50-50 in comparison to the shallower root system in the 100-100-100 treatment. From this, we can infer that the 100-100-100 treatment, because of its shallower root architecture, is likely more inherently susceptible to drought stress between irrigation events as surface soil layers dry down 


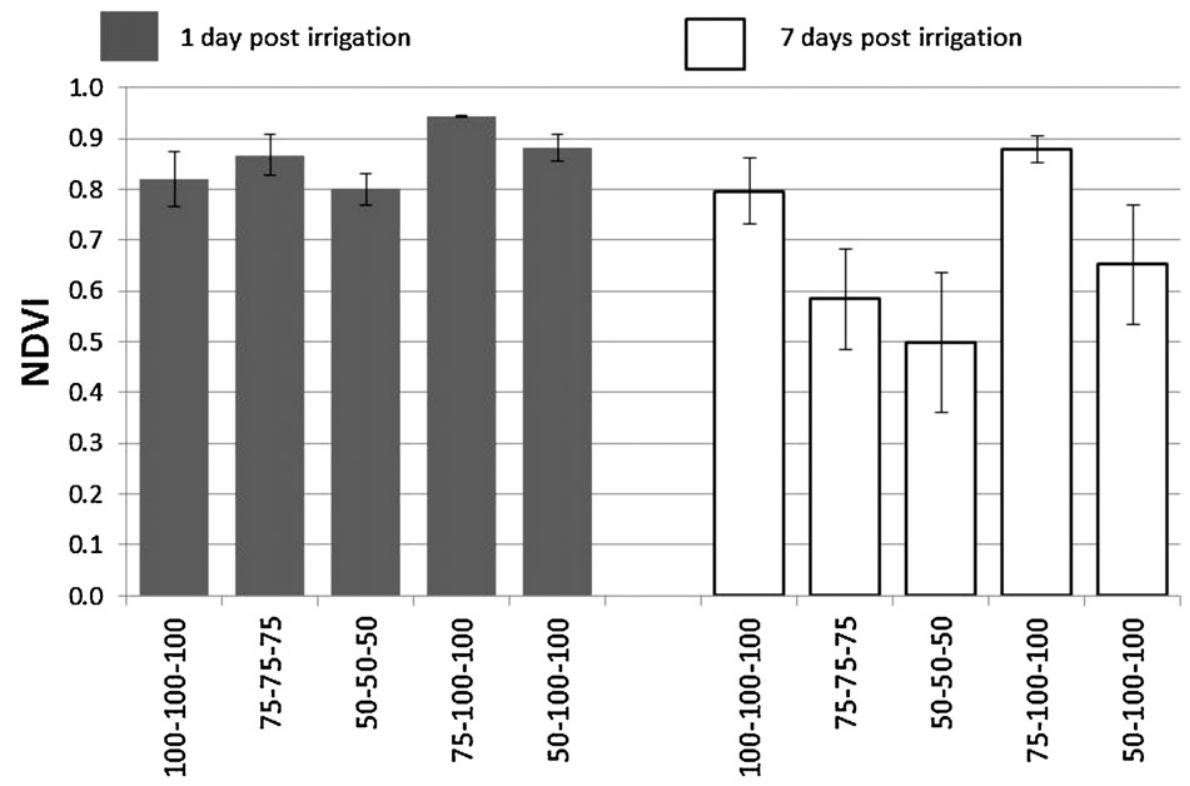

Fig. 8. NDVI measurements taken in the Texas field site over a 7 day period between irrigation events. All measurements were performed at mid-day.
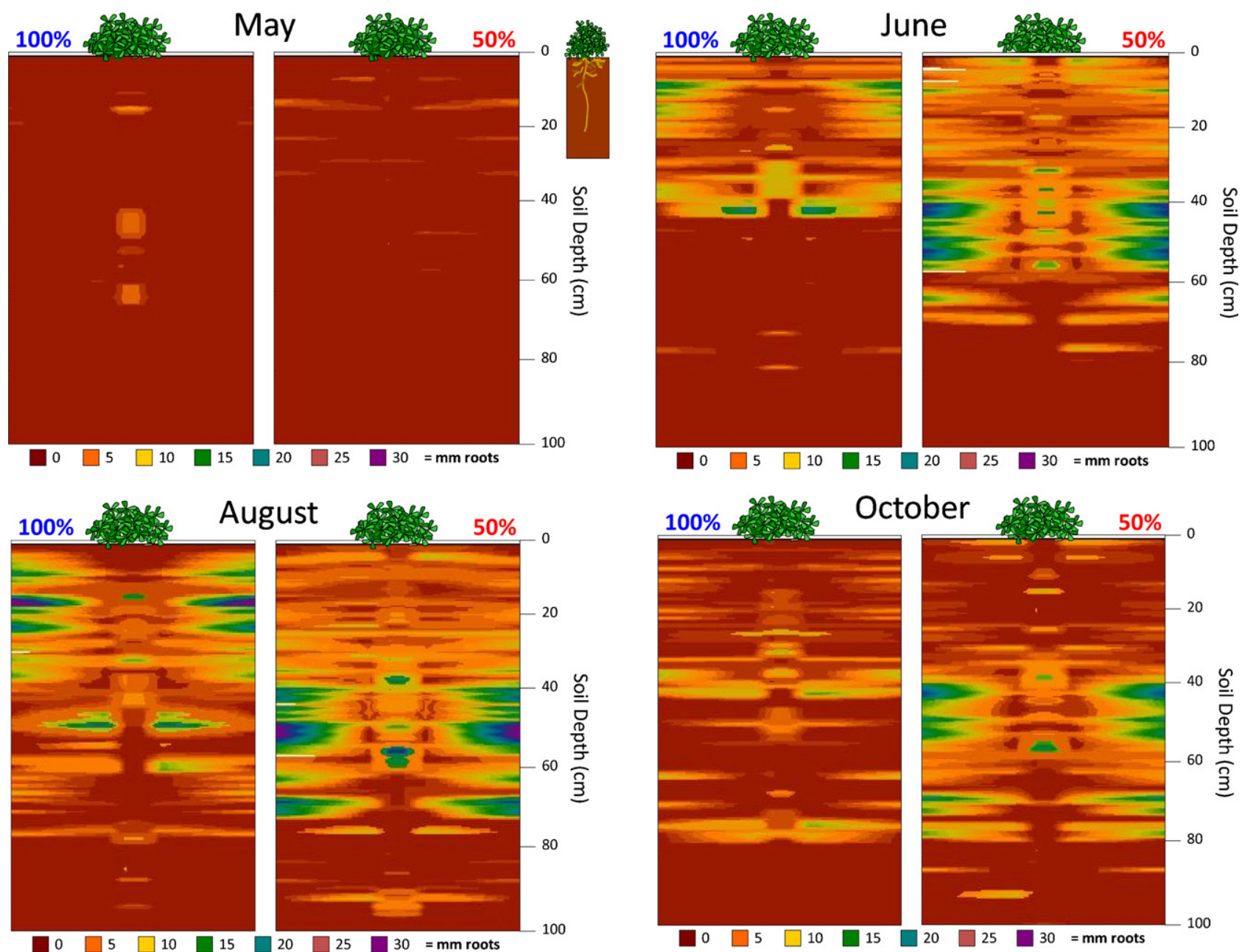

Fig. 9. Rooting profile in 2006 for 100-100-100 (100\%) and 50-50-50 (50\%) treatments (all season). Measurements were taken in May, June, August, and October. Different colors represent different lengths of roots present at each depth; cross sections illustrate the lateral spread across the row. (For interpretation of the references to color in this figure legend, the reader is referred to the web version of the article.) 
faster than the deeper soil layers where the majority of the roots in the 50-50-50 treatment were located. Because we see these differences between the two irrigation systems develop within a mere 30 days after planting (well before the full irrigation phase begins in the 50 PA treatment), we can assume the 50 PA root system was similar in these beneficial architectural traits as well. This may help explain why the 50 PA treatment was able to maintain yield similar to the 100-100-100 treatment with less water; the 50 PA treatment may have been benefiting from increased soil moisture uptake through its more developed root system. Increases in root/shoot ratio can be a common response to drought stress in crops (Blum, 1988), usually assumed to be through an overall decrease in shoot dry matter at a rate that is faster than decreases in root dry matter (Blum, 1996). However, there is evidence that absolute increases in root weight can also occur under water deficit (Malik et al., 1979) and this may be the case for peanut (Kheira, 2009). The mechanism behind an overall increase in root growth under water deficit, as was found in the current study, is the process whereby carbon assimilation is maintained at close to normal levels while leaf expansion is inhibited. In this case, the excess carbon may be allocated to support additional root growth (Blum, 1996). This supports the hypothesis and the results of the current study that mild drought stress may not always have adverse effects.

\section{Conclusion}

This study has shown that moderately reducing irrigation during early vegetative stages may allow producers to maintain economically viable peanut yields under reduced water resources in this semi-arid region. In particular, strategies that impose mild water deficits early in the season with full irrigation for the remainder of the season were adequate for maintaining yield and net return comparable to full irrigation. We have termed these strategies primed acclimation (PA). There is also evidence that PA aids the crop by enhancing reproductive output through increased and accelerated flower and peg production; maintaining overall crop NDVI through the season and between irrigation events; and improving root production. The data from this study could be instrumental in providing irrigation application guidelines for producers in the region through the use of crop development models like AquaCrop (Geerts et al., 2010). This approach may be the best avenue for defining appropriate water deficit levels because in-season crop sensors, like NDVI, may not provide the necessary differentiation between stress levels. Sustainable irrigation guidelines are essential for the sustainability of peanut production in west Texas because of the impending depletion of the primary aquifer water source (Opie, 2000). In 2005 and 2006, water was supplied to the pivot in the field where this study was conducted from three linked sub-surface wells. In 2010, seven linked sub-surface wells were required but could only supply water to half the previous pivot area. This study shows that a successful RDI program in peanut in the west Texas production region would employ mild to moderate drought stress confined to the early developmental period extending from stand establishment to peak flowering. Thereafter, full irrigation or natural rainfall would be required for high yield and grade.

\section{Acknowledgements}

We gratefully thank Jimbo and Jeremy Grissom for their generosity and adventurous spirit in allowing us to conduct this research on their farm. We are indebted to Larry Powell, John Gardner, Manuel Hall, and Bobby Ray Hagler for their expertise and efforts in establishing the irrigation treatments and sensors in the field as well as harvesting. The success of the project also depended on the talent and dedication of Andrew Tredennick, who performed the daily maintenance and data collection of the plots, as well as Blake Watkins, J.R. Quilantan, and Marie Syapin who helped perform plot maintenance and field measurements.

\section{References}

Awal, M.A., Ikeda, T., 2002. Recovery strategy following the imposition of episodic soil moisture deficit in stands of peanut (Arachis hypogaea L.). Journal of Agronomy and Crop Science 188, 185-192.

Blum, A., 1988. Plant Breeding for Stress Environments. CRC Press, Boca Raton, FL, $233 \mathrm{pp}$.

Blum, A., 1996. Crop responses to drought and the interpretation of adaptation. Plant Growth Regulation 20,135-148.

Boote, K.J., Ketring, D.L., 1990. Peanut. In: Stewart, B.A., Nielsen, D.R. (Eds.), Irrigation of Agricultural Crops. ASA, CSSA, SSA, Madison, WI, pp. 675-717.

Chaves, M.M., Maroco, J.P., Pereira, J.S., 2003. Understanding plant responses to drought - from genes to the whole plant. Functional Plant Biology 30, 239-264.

Chaves, M.M., Oliveira, M.M., 2004. Mechanisms underlying plant resilience to wate deficits: prospects for water-saving agriculture. Journal of Experimental Botany $55,2365-2384$.

Costa, J.M., Ortuño, M.F., Chaves, M.M., 2007. Deficit irrigation as a strategy to save water: physiology and potential application to horticulture. Journal of Integrative Plant Biology 49, 1421-1434.

Fereres, E., Soriano, M.A., 2007. Deficit irrigation for reducing agricultural water use Journal of Experimental Botany 58, 147-159.

Flexas, J., Bota, J., Galmés, J., Medrano, H., Ribas-Carbó, M., 2006. Keeping a positive carbon balance under adverse conditions: responses of photosynthesis and respiration to water stress. Physical Plant 127, 343-352.

Geerts, S., Raes, D., 2009. Deficit irrigation as an on-farm strategy to maximize crop water productivity in dry areas. Agricultural Water Management 96, 1275-1284.

Geerts, S., Raes, D., Garcia, M., 2010. Using AquaCrop to derive deficit irrigation schedules. Agricultural Water Management 98, 213-216.

Girona, J., Mata, M., Goldhamer, D.A., Johnson, R.S., DeJong, T.M., 1993. Patterns of soil and tree water status and leaf functioning during regulated deficit irrigation scheduling in peach. Journal of the American Society for Horticultural Science 118 (5), 580-586.

IPCC, 2001. Climate change 2001: the scientific basis. In: Houghton, J.T., Ding, Y., Griggs, D.J., Noguer, M., van der Linden, P.J., Xiaosu, D. (Eds.), Contribution of Working Group I to the Third Assessment Report of the Inter-Governmental Panel on Climate Change (IPCC). Cambridge University Press, Cambridge, UK.

Kang, S., Shi, W., Zhang, J., 2000. An improved water-use efficiency for maize grown under regulated deficit irrigation. Field Crops Research 67, 207-214.

Kang, S., Zhang, L., Liang, Y., Hu, X., Cai, H., Gu, B., 2002. Effects of limited irrigation on yield and water use efficiency of winter wheat in the Loess Plateau of China. Agricultural Water Management 55, 203-216.

Karam, F., Saliba, R., Breidy, J., Rouphael, Y., Balendonck, J., 2011. Yield and water use of eggplants (Solanum melongena L.) under full and deficit irrigation regimes. Agricultural Water Management 98, 1307-1316.

Kheira, A.A.A., 2009. Macromanagement of deficit-irrigated peanut with sprinkler irrigation. Agricultural Water Management 9, 1409-1420.

Kottapalli, K.R., Rakwal, R., Shibato, J., Burow, G., Tissue, D., Burke, J., Puppala, N., Burow, M., Payton, P., 2009. Physiology and proteomics of the water-deficit stress response in three contrasting peanut genotypes. Plant, Cell and Environment 32, 380-407.

Mahan, J.R., Burke, J.J., Wanjura, D.F., Upchurch, D.R., 2005. Determination of temperature and time thresholds for BIOTIC irrigation of peanut on the southern high plains of Texas. Irrigation Science 23, 145-152.

Mahey, R.K., Singh, R., Sidhu, S.S., Narang, R.S., 1991. The use of remote sensing to assess the effects of water stress in wheat. Experimental Agriculture 27 423-429.

Malik, R.S., Dhankar, J.S., Turner, N.C., 1979. Influence of soil water deficits on root growth of cotton seedlings. Plant and Soil 53, 109-115.

Mitchell, P.D., Jerie, P.H., Chalmers, D.J., 1984. The effects of regulated water deficits on pear tree growth, flowering, fruit growth and yield. Journal of the American Society for Horticultural Science 109, 604-606.

NASS (National Agricultural Statistics Service), USDA, 2007. Crop Production Annua Summary.

Ong, C.K., 1984. The influence of temperature and water deficits on the partitioning of dry matter in groundnut (Arachis hypogaea L.). Journal of Experimental Botany $35,746-755$

Opie, J., 2000. Ogallala: Water for a Dry Land. Univ. Nebraska Press, Lincoln, NE.

Payero, J.O., Melvin, S.R., Irmak, S., Tarkalson, D., 2006. Yield response of corn to deficit irrigation in a semiarid climate. Agricultural Water Management 84 $101-112$.

Peñuelas, J., Filella, I., Biel, C., Serrano, L., Savé, R., 1993. The reflectance at the $950-970 \mathrm{~nm}$ region as an indicator of plant water status. International Journal of Remote Sensing 14, 1887-1905.

Peñuelas, J., Gamon, J.A., Fredeen, A.L., Merino, J., Field, C.B., 1994. Reflectance indices associated with physiological changes in nitrogen- and water-limited sunflower leaves. Remote Sensing of Environment 48, 135-146.

Peñuelas, J., Inoue, Y., 1999. Reflectance indices indicative of changes in water and pigment contents of peanut and wheat leaves. Photosynthetica 36, 355-360.

Perkins, S., 2002. Crisis on tap? Pollution and burgeoning populations stress earth's water resources. Science News 162, 33-48. 
Rao, R.C.N., Singh, S., Sivakumar, M.V.K., Srivastava, K.L., Williams, J.H., 1985. Effect of water deficit at different growth phases of peanut. I. Yield responses. Agronomy Journal 77, 782-786.

Stansell, J.R., Pallas Jr., J.E., 1985. Yield and quality response of Florunner peanut to applied drought at several growth stages. Peanut Science 12 (2), 64-70.

Stewart, W.L., Fulton, A.E., Krueger, W.H., Lampinen, B.D., Shackel, K.A., 2011. Regulated deficit irrigation reduces water use of almonds without affecting yield. California Agriculture 65, 90-95.
USDA (United States Department of Agriculture), 1993. Milled peanuts: Inspection instructions. USDA, Agricultural Marketing Service, Fruit and Vegetable Division, Washington, DC.

Wright, G.C., Hubick, K.T., Farquhar, G.D., 1991. Physiological analysis of peanut cultivar response to timing and duration of drought stress. Australian Journal of Agricultural Research 42, 453-470.

Zhang, B., Li, F., Huang, G., Cheng, Z., Zhang, Y., 2006. Yield performance of spring wheat improved by regulated deficit irrigation in an arid area. Agricultural Water Management 79, 28-42. 